\title{
The Impact of Childhood Neglect on Cognition in School-Aged Children
}

\author{
Heather Boughey, Gemma Trainor* and Grahame Smith \\ Department of Mental Health Nursing, Liverpool John Moores University, England \\ *Corresponding author: Gemma Trainor, Department of Mental Health Nursing, Liverpool John Moores University, \\ England
}

\section{ARTICLE INFO}

Received: 蔧 March 26, 2021

Published: 幽 April 05, 2021

Citation: Heather Boughey, Gemma Trainor, Grahame Smith. The Impact of Childhood Neglect on Cognition in School-Aged Children. Biomed J Sci \& Tech Res 34(5)2021. BJSTR. MS.ID.005629.

Keywords: Childhood Neglect; Cognitive Function; Child Mental Health; Scoping Review; Intelligence; Language; Memory; Executive Function; Academic Achievement

\section{ABSTRACT}

Childhood neglect is the most ubiquitous and prevalent form of adverse childhood experiences (ACEs). Given the significance of cognitive function and its malleability in retort to environmental stimuli, there is significant relevance in understanding the impact of child neglect on cognitive domains. Furthermore, examining the cognitive domains individually enables a more nuanced understanding of the impact of childhood neglect. This article details a scoping review undertaken to explore the relationship between childhood neglect and cognitive function, with the aim to recognize the observable cognitive qualities in neglected children, in the absenteeism of other ACEs. Cognitive function was divided into five domains: executive function, academic achievement, language, memory and intelligence. The findings demonstrated that executive function (working memory and attention shifting), language and intelligence were associated with childhood neglect, and there was no association between executive function (spatial planning), academic achievement, memory and childhood neglect.

\section{Introduction}

Adverse childhood experiences or ACEs are stressful and traumatic events that arise in a child's early life Felitti (1998) et al. [1]; McLaughlin (2019) et al. [2]. ACEs is an umbrella term for different types of early adversity Peterson (2013) [3]. This includes direct harm to children otherwise known as child maltreatment McLaughlin (2019) et al. [2] and includes physical abuse, sexual abuse, and/or neglect. ACEs can also be indirect through their living environments, for example through parental conflict, mental illness or substance abuse Hughes et (2017) et al. [4]. Differentiating between the impact of different ACEs is difficult, as studies historically present findings as a combined cumulative risk score rather than distinct ACEs Evans (2013) et al. [5].

Childhood neglect is the most ubiquitous and prevalent form of ACEs English (2005) et al. [6] Maguire (2015) et al. [7]. Although it is associated with substantial mortality Dubowitz (2004) et al. [8], it is the least empirically studied form of child maltreatment De Bellis (2005) [9]. The significance of child neglect should come as no surprise, given that a lack of parental care, a trademark of neglect, is an extreme risk to children's growth and well-being Rutter (2000) et al. [10].
As schools are obliged to take accountability for promoting and safeguarding the welfare of young children Great Britain (2002) [11], distinguishable characteristics of school-aged children facing neglect need to be taken from recent literature Maguire (2015) et al. [7]. Teachers and schooling staff interact with the same children on a virtually daily basis. Therefore, they are in the best setting to witness the children's behaviour Burgess 2011 et al. [12]. McGarry and Buckley, 2013 [13] International research highlights that teachers feel uncomfortable with the idea of notifying child protection services of suspected or known neglect Gilbert [14]. Their response was mainly due to a lack of knowledge regarding the signs of neglect [12].

Children's environments structure their cognitive function Nisbett (2012) et al. [15]. A child must develop through the cognitive development stages for future health and achievement Noble (2015) et al. [16]. Given the significance of cognitive function and its malleability in retort to environmental stimuli [15] there is significant interest in understanding the impact of neglect on cognitive outcomes Guinosso (2016) et al. [17]. 
Once neglected children start in education, indicators of academic concern rapidly appear Peterson (2013) et al. [3]. Academic achievement signifies performance outcomes that signify the degree to which a child has completed educational objectives Woolfolk (2007) [18]. In a longitudinal study, neglected children in kindergarten were regarded by their teachers as having more trouble understanding school tasks, compared to children who had not been neglected Erickson (1989) et al. [19]. By second grade, most of the neglected children had been referred to special education services Egeland (1991) [20]. This display of academic difficulties increased during their school years and was seen through into adolescence Egeland (1997) [21].

Moreover, childhood neglect and the impact on the language domain has been previously studied Eigsti (2004) [21]. Language is a structured system of communication and involves skills such as listening and reading (receptive skills) and writing and speaking (productive skills; Trask (2007) [22]). Language delay becomes more evident as children grow older, with research finding that neglected children demonstrated more syntactic delays and reduced vocabulary than control groups [23]. Language delay is also apparent when child maltreatment types are compared. Children who had been neglected had more delays in receptive language (auditory comprehension) and expressive language (verbal ability) than children who had been physically abused Allen (1982) et al. [24]; Culp (1991) [25].

While previous reviews have been published looking at ACEs and cognitive function Maguire (2015) [11]; Guinosso (2016) [17]; Kavanaugh (2017) et al. [26]; Carlson (2019) [27]; Yingying (2019) [28]. Most reviews Guinosso et al. [25-28] focus on child maltreatment as a homogenous group and do not differentiate between child abuse and child neglect [3]. Others combine child neglect and emotional abuse Maguire 2015 [7]. In recent years, there has been increased attention to isolate specific ACEs for targeted interventions and to identify the specific characteristics such children display McLaughlin (2014) [2,29].

This article details a scoping review that was undertaken to explore the relationship between childhood neglect and cognitive function. To recognize the observable cognitive qualities in neglected children, in the absenteeism of other ACEs, to gain a better understanding of the behaviours they may exhibit.

\section{Aim}

To provide a comprehensive overview of the impact of childhood neglect on cognition in school-aged children.

\section{Method}

The process and results reporting were guided by the Preferred Reporting Items for Systematic Reviews and MetaAnalysis (PRISMA) guidelines, 2009 revision Moher (2009) [30].
Three databases - MEDLINE, PsycINFO and Cumulative Index to Nursing and Allied Health Literature (CINAHL) - were searched using the following terms: (S1) childhood: child*, early childhood, middle childhood; (S2) neglect: early neglect, neglect, emotional neglect*, physical* neglect* and (S3) cognition: cognit*, language, visuospatial, memory, attention, executive function*, intelligen*. Truncation symbols and the boolean operator 'AND' was used in the advanced search strategy to link the different groupings of search terms (S1 AND S2 AND S3).

The inclusion criteria were that the studies had to:

a) Be peer-reviewed research.

b) Involve school-aged children (6-12 years of age) with confirmed cases of neglect by child protection services (CPS) or other governed bodies.

c) Explore the outcome of cognitive domains.

d) Have been published in an academic journal in the English language, between January 2010 and January 2020

Neglect is defined as the inability to offer health, education, emotional development, nutrition and secure living environments, for the development of the child. Also, if there is a high possibility of causing harm to the child's mental, physical, spiritual or social development. This involves the inability to appropriately supervise and safeguard children from harm harm (World Health Organisation, 1999) [31].

Studies that focused on other ACEs, such as physical, sexual, and/or emotional abuse were excluded. Case studies, literature reviews and grey literature were also excluded. Of the 483 articles initially identified, 89 articles were excluded due to duplication. 394 articles were screened for relevance. On reviewing the titles and abstracts, 340 articles were excluded, as they were found not to meet the inclusion criteria. With the remaining 54 articles, full-text articles were assessed and 42 were excluded, leaving 12 articles. One additional article of interest was identified when screening the reference lists of the 12 final articles. Therefore, a total of 13 studies were included in the review. The Consolidated Standards of Reporting Trials (CONSORT) checklist was used to critically appraise the quality and the reliability of the included studies, none of which were rejected based on the appraisal Moher (2010) [32].

Figure 1 is a PRISMA flow diagram, to present the flow of information through different stages. Table 1 provides a summary of the studies included in the scoping review. Once the articles had been selected, data of each study's aim, population, method and findings were extracted. The data extracted from each study were entered into a table to summarize the included studies. The authors challenged each other's interpretations and worked collaboratively to deepen the discussion and interpretation and enhance rigour and quality Whiting (2017) [33]. 


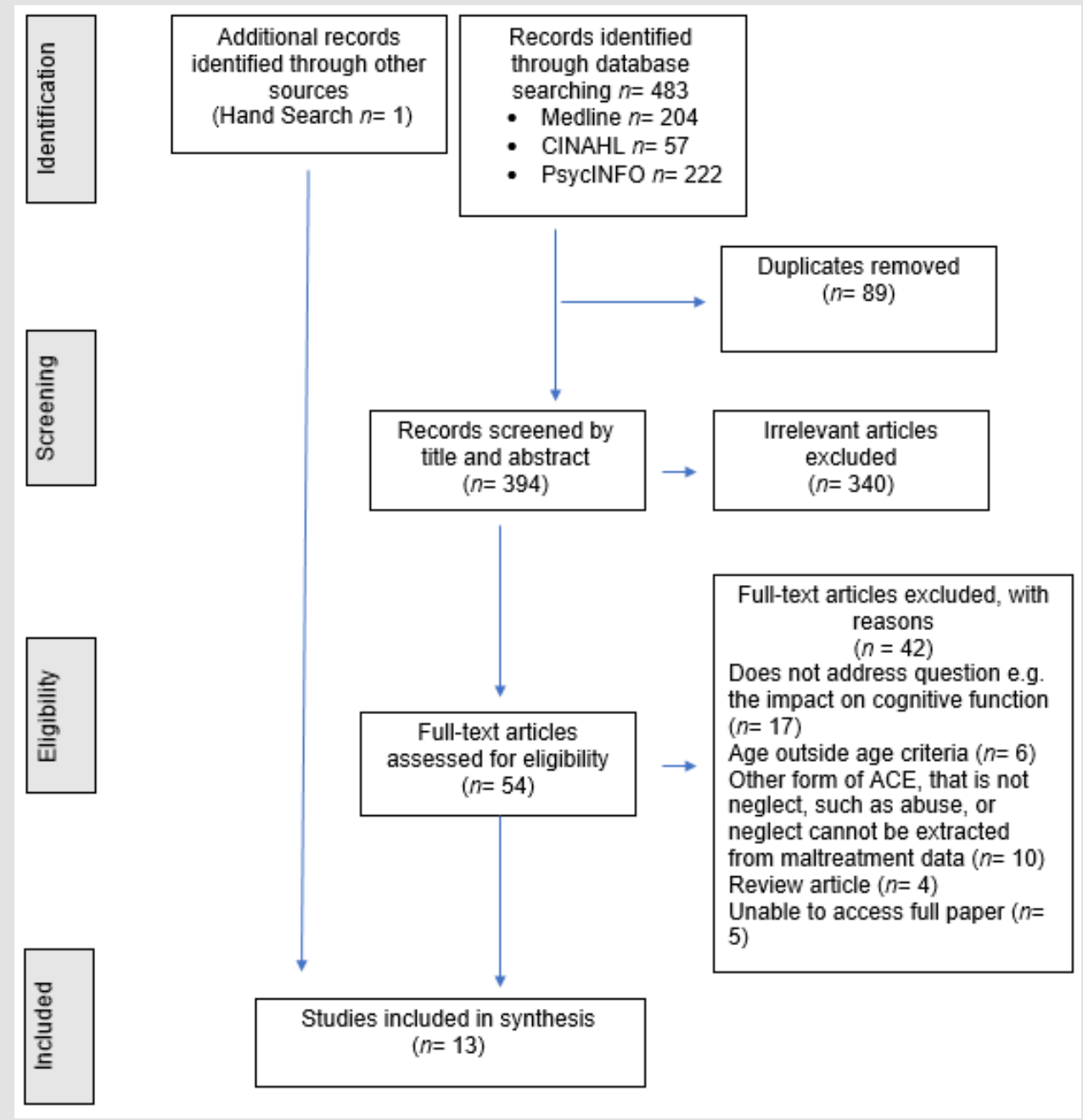

Figure 1: PRISMA flow diagram.

Table 1: Summary of the studies included in the scoping review.

\begin{tabular}{|c|c|c|c|c|c|c|c|c|c|}
\hline $\begin{array}{l}\text { Study } \\
\text { Author }\end{array}$ & Sample & Exclusion & $\begin{array}{l}\text { Neglect } \\
\text { group }\end{array}$ & Control group & $\begin{array}{c}\text { Maltreatment } \\
\text { type }\end{array}$ & $\begin{array}{l}\text { Domains } \\
\text { assessed }\end{array}$ & $\begin{array}{l}\text { Relevant } \\
\text { non- } \\
\text { significant } \\
\text { findings }\end{array}$ & $\begin{array}{l}\text { Significant } \\
\text { findings }\end{array}$ & $\begin{array}{l}\text { Located } \\
\text { from }\end{array}$ \\
\hline $\begin{array}{l}\text { Bengwasan } \\
\text { (2018) [52] }\end{array}$ & $\begin{array}{c}\text { Referred by } \\
\text { DWSD and } \\
\text { NGOs }\end{array}$ & $\begin{array}{l}\text { Children with } \\
\text { verbal, EA or } \\
\text { psychological } \\
\text { abuse, or } \\
\text { co-occurring } \\
\text { types of abuse. } \\
\text { Previously } \\
\text { taken the } \\
\text { tests or have } \\
\text { intellectual or } \\
\text { neuro-cognitive } \\
\text { conditions. }\end{array}$ & $\begin{array}{l}300 \text { children } \\
\text { aged } 4-17 \\
\text { years } \\
\text { grouped } \\
100 \text { in PA, } \\
100 \mathrm{SA} \text { and } \\
100 \text { children } \\
\text { in neglect } \\
\text { group }\end{array}$ & $\mathrm{N} / \mathrm{A}$ & $\begin{array}{l}\text { SA, PA, and } \\
\text { Neglect }\end{array}$ & Intelligence & $\mathrm{N} / \mathrm{A}$ & $\begin{array}{l}\text { PA mean } \\
\text { higher score } \\
\text { in SB5 and all } \\
\text { indices than } \\
\text { SA and N }\end{array}$ & Medline \\
\hline
\end{tabular}




\begin{tabular}{|c|c|c|c|c|c|c|c|c|c|}
\hline $\begin{array}{l}\text { Bick (2018) } \\
\text { et al. [39] }\end{array}$ & $\begin{array}{l}\text { Children who } \\
\text { participated } \\
\text { previously in } \\
\text { BEIP }\end{array}$ & $\mathrm{N} / \mathrm{A}$ & $\begin{array}{l}150 \text { children } \\
8-10 \text { years of } \\
\text { age grouped } \\
\text { (1) } 49 \text { in } \\
\text { care as usual } \\
\text { group, (2) } \\
50 \text { in foster } \\
\text { group }\end{array}$ & $\begin{array}{l}\text { (3) } 51 \\
\text { children never } \\
\text { institutionalised } \\
\text { group }\end{array}$ & $\begin{array}{l}\text { Institutional } \\
\text { neglect }\end{array}$ & $\begin{array}{l}\text { Executive } \\
\text { function and } \\
\text { memory }\end{array}$ & $\begin{array}{l}\text { No change } \\
\text { from 8-12 } \\
\text { years across } \\
\text { all tasks }\end{array}$ & $\begin{array}{l}\text { Institutionally } \\
\text { reared } \\
\text { children } \\
\text { showed poorer } \\
\text { performance } \\
\text { on memory } \\
\text { and executive } \\
\text { function tasks }\end{array}$ & Medline \\
\hline $\begin{array}{l}\text { Chae } \\
\text { (2011) et } \\
\text { al. [51] }\end{array}$ & $\begin{array}{l}\text { Inpatient unit } \\
\text { - referrals } \\
\text { from CPS }\end{array}$ & $\mathrm{N} / \mathrm{A}$ & 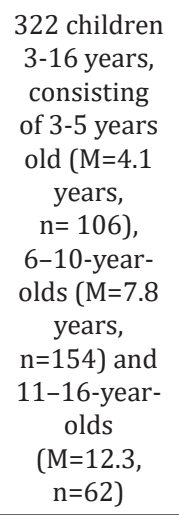 & $\begin{array}{c}\text { Control group } \\
\text { - no abuse or } \\
\text { neglect }\end{array}$ & $\begin{array}{l}\text { SA, PA, both } \\
\text { sexual and } \\
\text { physical abuse } \\
\text { and neglect }\end{array}$ & Memory & $\begin{array}{l}\text { Abuse and } \\
\text { neglect } \\
\text { not found } \\
\text { to affect } \\
\text { memory }\end{array}$ & N/A & Medline \\
\hline $\begin{array}{l}\text { Cicchetti } \\
\text { (2010) et } \\
\text { al. [50] }\end{array}$ & $\begin{array}{l}\text { Identified by } \\
\text { DHS }\end{array}$ & $\mathrm{N} / \mathrm{A}$ & $\begin{array}{c}317 \\
\text { Children of } \\
\text { an average } \\
\text { age of } 9.17 \\
\text { years old } \\
(\mathrm{SD}=2.43, \\
\text { range: } \\
6-13)-(1) \\
\text { maltreated } \\
\text { group } \\
(\mathrm{n}=143)\end{array}$ & $\begin{array}{l}\text { Non-maltreated } \\
\text { group (n-174) }\end{array}$ & $\begin{array}{c}\text { Neglect } \\
\text { (physical), } \\
\text { emotional } \\
\text { maltreatment, } \\
\text { PA, and SA }\end{array}$ & Memory & $\begin{array}{l}\text { Basic } \\
\text { recall and } \\
\text { recognition } \\
\text { memory in } \\
\text { neglect, did } \\
\text { not differ } \\
\text { from control }\end{array}$ & $\begin{array}{l}\text { Cortisol } \\
\text { level to false } \\
\text { recognition } \\
\text { in neglect and } \\
\text { emotional } \\
\text { maltreatment. } \\
\text { PN/EM has } \\
\text { increased false } \\
\text { recognition } \\
\text { memory }\end{array}$ & Medline \\
\hline $\begin{array}{l}\text { De Bellis, } \\
\text { Woolley } \\
\text { and Hooper } \\
\text { (2013) [9] }\end{array}$ & CPS & $\begin{array}{c}\mathrm{IQ}<70, \text { a } \\
\text { disability, a } \\
\text { significant } \\
\text { medical illness, } \\
\text { head injury or } \\
\text { neurological } \\
\text { disorder, birth } \\
\text { weight }<5 \mathrm{lbs} \\
\text { and prenatal } \\
\text { complications }\end{array}$ & $\begin{array}{c}\text { Children } \\
\text { aged } \\
6-17-(1) \\
\text { Maltreated } \\
\text { group } \\
\text { (n=38) (age } \\
\text { - M=11.87, } \\
\text { SD=3.08) } \\
\text { and (2) } \\
\text { maltreated + } \\
\text { PTSD group } \\
\text { (n=60) } \\
(\mathrm{M}=11.74 \\
\mathrm{SD}=3.32)\end{array}$ & $\begin{array}{l}\text { Control group } \\
\begin{array}{c}\text { (3) youth } \\
(\mathrm{n}=104) \\
(\mathrm{M}=12.52 \\
\mathrm{SD}=3.04) .\end{array}\end{array}$ & $\begin{array}{l}\text { Witnessing } \\
\text { domestic } \\
\text { violence, PA, } \\
\text { SA, EA, and } \\
\text { Neglect }\end{array}$ & $\begin{array}{l}\text { Language } \\
\text { and memory }\end{array}$ & $\begin{array}{l}\text { Did not reveal } \\
\text { distinct } \\
\text { profiles } \\
\text { between } \\
\text { the two } \\
\text { maltreatment } \\
\text { groups, } \\
\text { no group } \\
\text { differences } \\
\text { in the fine } \\
\text { motor } \\
\text { domain }\end{array}$ & $\begin{array}{l}\text { Generally, } \\
\text { failure to } \\
\text { supervise } \\
\text { index and } \\
\text { failure to } \\
\text { provide has } \\
\text { lower scores } \\
\text { than other } \\
\text { maltreatment } \\
\text { groups in } \\
\text { all cognitive } \\
\text { domains }\end{array}$ & Medline \\
\hline $\begin{array}{l}\text { Hanson } \\
(2013) \\
\text { et al. [38] }\end{array}$ & $\begin{array}{l}\text { Recruited } \\
\text { from CPS }\end{array}$ & $\mathrm{N} / \mathrm{A}$ & $\begin{array}{l}63 \text { children } \\
(25 \text { who had } \\
\text { experienced } \\
\text { early } \\
\text { neglect })- \\
\text { between the } \\
\text { ages of } 9 \text { and } \\
14 \text { years of } \\
\text { age (Mean } \\
\text { age }=140.42 \\
+/-19.87 \\
\text { months) }\end{array}$ & $\begin{array}{c}38 \text { children } \\
\text { who had not } \\
\text { experienced } \\
\text { neglect (Mean } \\
\text { age }=142.43+/- \\
21.6 \text { months) }\end{array}$ & Neglect & $\begin{array}{l}\text { Memory and } \\
\text { executive } \\
\text { function }\end{array}$ & $\mathrm{N} / \mathrm{A}$ & $\begin{array}{l}\text { Children who } \\
\text { have suffered } \\
\text { early neglect } \\
\text { displayed } \\
\text { poorer } \\
\text { neurocognitive } \\
\text { performance } \\
\text { compared to } \\
\text { comparison } \\
\text { children - } \\
\text { more total } \\
\text { errors on the } \\
\text { IED, PAL, and } \\
\text { SWM and } \\
\text { solved fewer } \\
\text { problems on } \\
\text { the SOC }\end{array}$ & Medline \\
\hline
\end{tabular}




\begin{tabular}{|c|c|c|c|c|c|c|c|c|c|}
\hline $\begin{array}{l}\text { Lum, Powell } \\
\text { and, Snow } \\
\text { (2018) [47] }\end{array}$ & $\begin{array}{l}\text { Recruited by } \\
\text { government } \\
\text { records of } \\
\text { CPA }\end{array}$ & $\mathrm{N} / \mathrm{A}$ & $\begin{array}{c}82 \text { children } \\
\text { aged } \\
\text { between } 5 \\
\text { and } 12 \text { years } \\
\text { old }\end{array}$ & $\mathrm{N} / \mathrm{A}$ & $\begin{array}{c}\text { PA, SA, EA, and } \\
\text { Neglect }\end{array}$ & Language & $\begin{array}{l}\text { Language } \\
\text { functioning } \\
\text { was not } \\
\text { related to the } \\
\text { presence of } \\
\text { neglect }\end{array}$ & $\mathrm{N} / \mathrm{A}$ & PsycINFo \\
\hline $\begin{array}{c}\text { McGuire } \\
\text { and Jackson } \\
\text { (2018) [43] }\end{array}$ & $\begin{array}{l}\text { Records are } \\
\text { taken from } \\
\text { DSS }\end{array}$ & $\begin{array}{c}\text { Prior ASD or } \\
\text { psychosis, or } \\
\text { non-native } \\
\text { English speaker }\end{array}$ & $\begin{array}{l}490 \text { youths } \\
\text { aged } \\
\text { between } 8 \\
\text { and } 18 \text { in } \\
\text { foster care }\end{array}$ & $\mathrm{N} / \mathrm{A}$ & $\begin{array}{c}\text { Neglect, EA PA, } \\
\text { and SA }\end{array}$ & $\begin{array}{c}\text { Academic } \\
\text { Achievement }\end{array}$ & $\begin{array}{c}\text { Neglect } \\
\text { frequency } \\
\text { and severity } \\
\text { was not } \\
\text { associated } \\
\text { with school } \\
\text { grades }\end{array}$ & $\begin{array}{c}\text { Only neglect } \\
\text { was a } \\
\text { marginally } \\
\text { significant } \\
\text { predictor of } \\
\text { English grades }\end{array}$ & PsycINFO \\
\hline $\begin{array}{l}\text { Manly } \\
\text { (2013) et } \\
\text { al. [42] }\end{array}$ & $\begin{array}{c}\text { Recruiter } \\
\text { through DHS }\end{array}$ & $\mathrm{N} / \mathrm{A}$ & $\begin{array}{c}170 \text { children } \\
\text { - maltreated } \\
\text { children } \\
(n=111) \\
\text { between } 4 \\
\text { and } 6 \text { years } \\
\text { of age }\end{array}$ & $\begin{array}{c}\text { Non maltreated } \\
\text { group }(n=59)\end{array}$ & $\begin{array}{l}\text { Maltreatment } \\
\text { - defined } \\
\text { as physical } \\
\text { neglect }\end{array}$ & $\begin{array}{c}\text { Academic } \\
\text { Achievement } \\
\text { and } \\
\text { intelligence }\end{array}$ & $\begin{array}{c}\text { Neglect } \\
\text { severity } \\
\text { not directly } \\
\text { associated } \\
\text { with } \\
\text { first-grade } \\
\text { academic } \\
\text { performance } \\
\text { but rather } \\
\text { indirectly } \\
\text { related to } \\
\text { cognitive } \\
\text { performance }\end{array}$ & $\begin{array}{c}\text { Neglect } \\
\text { associated } \\
\text { with decreased } \\
\text { language } \\
\text { (kindergarten) } \\
\text { and math } \\
\text { grades (first } \\
\text { grade) and } \\
\text { lower scores } \\
\text { overall on } \\
\text { first-grade } \\
\text { academic } \\
\text { achievement }\end{array}$ & Medline \\
\hline $\begin{array}{l}\text { O’Hara, } \\
\text { (2015) et } \\
\text { al. [53] }\end{array}$ & $\begin{array}{l}\text { The National } \\
\text { Center for } \\
\text { Child Abuse } \\
\text { and Neglect }\end{array}$ & $\begin{array}{l}\text { Neglect and/or } \\
\text { abuse was not } \\
\text { reported in the } \\
\text { first four years } \\
\text { of life }\end{array}$ & $\begin{array}{c}372 \text { children } \\
\text { assessed at } \\
\text { aged } 6.271 \\
\text { in neglect } \\
\text { only group, } \\
101 \text { in the } \\
\text { neglect + } \\
\text { physical } \\
\text { abuse group }\end{array}$ & $\mathrm{N} / \mathrm{A}$ & Neglect and PA & Intelligence & $\mathrm{N} / \mathrm{A}$ & $\begin{array}{l}\text { Neglect group } \\
\text { - scored } \\
\text { worse than } \\
\text { other groups } \\
\text { in vocab/ } \\
\text { language }\end{array}$ & Medline \\
\hline $\begin{array}{l}\text { Petrenko } \\
\text { (2012) et } \\
\text { al. [44] }\end{array}$ & $\begin{array}{l}\text { In out-of- } \\
\text { home care } \\
\text { because } \\
\text { of court } \\
\text { orders due to } \\
\text { maltreatment }\end{array}$ & $\begin{array}{l}\text { If they did not } \\
\text { experience } \\
\text { maltreatment } \\
\text { or records did } \\
\text { not provide } \\
\text { enough } \\
\text { information. } \\
\text { Not Spanish } \\
\text { and no } \\
\text { developmental } \\
\text { delays }\end{array}$ & $\begin{array}{l}334 \text { Children } \\
\text { aged 9-11 } \\
\text { years, placed } \\
\text { in out-of- } \\
\text { home care }\end{array}$ & $\mathrm{N} / \mathrm{A}$ & $\begin{array}{c}\text { SA, PA, Physical } \\
\text { Neglect, and } \\
\text { Supervisory } \\
\text { neglect }\end{array}$ & $\begin{array}{c}\text { Academic } \\
\text { Achievement } \\
\text { and } \\
\text { intelligence }\end{array}$ & $\begin{array}{l}\text { Physical } \\
\text { Neglect did } \\
\text { not predict } \\
\text { any DV's. } \\
\text { no subtype } \\
\text { difference in } \\
\text { nonverbal } \\
\text { scores or } \\
\text { academic } \\
\text { achievement }\end{array}$ & $\begin{array}{l}\text { Supervisory } \\
\text { Neglect } \\
\text { associated } \\
\text { with higher } \\
\text { verbal scores }\end{array}$ & Medline \\
\hline $\begin{array}{l}\text { Pollak } \\
\text { (2010) et } \\
\text { al. [40] }\end{array}$ & $\begin{array}{l}\text { Minnesota } \\
\text { and } \\
\text { Wisconsin } \\
\text { International } \\
\text { Adoption } \\
\text { Project } \\
\text { Registries }\end{array}$ & $\begin{array}{c}\text { IQ }<78 \text {, parents } \\
\text { reported } \\
\text { congenital } \\
\text { abnormalities } \\
\text { and failure } \\
\text { on the FAS } \\
\text { screener }\end{array}$ & $\begin{array}{l}132 \text { children } \\
\text { aged } \\
\text { between } \\
\text { 8-9 years. } \\
3 \text { groups } \\
\text { (1) post- } \\
\text { institutional } \\
\text { - PI. (2) } \\
\text { early } \\
\text { adopted } \\
\text { group- EA }\end{array}$ & $\begin{array}{l}\text { (3) children } \\
\text { born and raised } \\
\text { with their birth } \\
\text { families - NA }\end{array}$ & $\begin{array}{l}\text { Institutional } \\
\text { Neglect/ } \\
\text { Deprivation }\end{array}$ & $\begin{array}{c}\text { Executive } \\
\text { function and } \\
\text { memory }\end{array}$ & $\mathrm{N} / \mathrm{A}$ & $\begin{array}{l}\text { PI performed } \\
\text { poorly than } \\
\text { both EA and } \\
\text { NA on SWM, } \\
\text { PAL, and } \\
\text { Attention }\end{array}$ & $\begin{array}{c}\text { Hand search } \\
\text { - Found in } \\
\text { Hanson, et al } \\
\text { (2013) }\end{array}$ \\
\hline
\end{tabular}




\begin{tabular}{|c|c|c|c|c|c|c|c|c|c|}
\hline $\begin{array}{l}\text { Spratt et al. } \\
\text { (2012) [48] }\end{array}$ & $\begin{array}{c}\text { Data } \\
\text { obtained } \\
\text { from CPS }\end{array}$ & $\begin{array}{l}\text { Children with } \\
\text { malnutrition, } \\
\text { obesity, birth } \\
\text { complication, } \\
\text { neurobiological } \\
\text { disorders, } \\
\text { medical } \\
\text { conditions, } \\
\text { and children in } \\
\text { current CPS }\end{array}$ & $\begin{array}{c}\text { Children } \\
\text { aged 3-10 } \\
\text { years. (1) } \\
17 \text { children } \\
\text { with a } \\
\text { history of } \\
\text { familial } \\
\text { neglect } \\
\text { (USN), (2) } \\
15 \text { children } \\
\text { with a } \\
\text { history of } \\
\text { institutional } \\
\text { rearing (IA) }\end{array}$ & $\begin{array}{l}\text { (3) } 28 \text { Children } \\
\text { without a } \\
\text { history of } \\
\text { neglect (control } \\
\text { group) }\end{array}$ & Neglect & Language & $\mathrm{N} / \mathrm{A}$ & $\begin{array}{l}\text { Compared } \\
\text { to those do } \\
\text { not neglect, } \\
\text { USN and IA } \\
\text { demonstrated } \\
\text { lower } \\
\text { cognitive } \\
\text { and language } \\
\text { scores }\end{array}$ & PsycINFO \\
\hline
\end{tabular}

\section{Findings}

The first stage of analysis was assessing the heterogeneity of the included articles. A high heterogeneity among these characteristics of included articles precluded the use of a meta-analysis. This is because high heterogeneity violates the underlying assumption of a normal distribution Higgins (2009) [34]. As recommended by the Cochrane review/collaboration Higgins (2019) [35] a narrative synthesis was used to explore the relationship between childhood neglect and cognitive function.

To provide a comprehensive review, cognitive function was divided into five subcategories: executive function, academic achievement, language, memory and intelligence Yingying (2019) [28]. Once all the articles had been grouped into subcategories, this made it substantially easier to explore the relationships within and between articles. Further grouping occurred for studies that used the same neurocognitive tests.

\section{Executive Function}

Executive function was divided into working memory, attention shifting and spatial planning. Whether executive function ought to be conceptualized as a unitary concept or several separate functions has been a matter of discussion Stuss and Alexander (2000) [36]. However, further research suggests executive function is best considered as distinct functions Blair (2005) et al. [37].

\section{Working Memory}

Using the Cambridge Neuropsychological Test and Automated Battery (CANTAB), spatial working memory task, one study Hanson (2013) et al. [38] found that children who had suffered early neglect have more total errors, compared to children who had not suffered early neglect $(\mathrm{p}<.001)$. Similar results were found by Bick et al. (2018) [39], children in the ever-institutionalized group made more total errors than children in the never institutionalized group. Those in the ever-institutionalized group also presented significantly worse strategy scores, relative to the never institutionalized group ( $\beta=-.341, \mathrm{p}<.001 ;$ [39]). Moreover, Pollak et al. [40] found there was a distinction amongst the groups on the spatial working memory (SWM) subtest, $F(2,128)=7.96, p=.001$. Post-institutionalized (neglected) children performed more poorly than both the emotional abuse $(p=.008)$ group and the control group $(\mathrm{p}=.001)$. The included studies all used the same CANTAB which ensured interstudy homogeneity and all studies found similar results. Therefore, this review will accept that childhood neglect is associated with the working memory domain.

\section{Attention Shifting}

Two studies found that neglected children showed significantly poor performance Hanson (2013) et al. [38]; Bick (2018) et al. [39]. In one study Bick (2018) et al. [39], the institutionalized group committed more total errors, even when amended for the number of levels accomplished, compared to those never institutionalized ( $\beta=-.327, p<.001)$. Similar results were found by Hanson (2013) et al. [38], who found that children with early neglect had more total errors than children who had not suffered neglect ( $\mathrm{p}=.012)$.

Conversely, Pollak (2010) [40] discovered no substantial differences between the three groups (institutional neglect, early adoption, and control group), with the intra-extra dimensional set-shifting (ID/ED) test $(\mathrm{p}>.05)$. Further tests on attention demonstrated that all groups performed similarly on auditory attention tests. However, the groups varied on the visual attention tests, as children in the post-institutionalized (neglected) group, $F(2,116)=8.96, p=.001$, performed more poorly than those in the early adoption group ( $p=.001)$ and control group $(p=.006)$. Although the included studies found mixed results, they all used the same CANTAB which ensured interstudy homogeneity. Pollak et al. (2010) [40] originally discovered no difference in attention shifting between the groups when using the ID/ED test. An explanation for this is the ability to voluntarily focus or shift attention cultivates between 7 and 9 years of age Anderson (2010) [41] and Pollak et al. (2010) [40] recruited participants between the ages of 8 and 9 years. Their capability to shift attention may not have fully developed by the study. Therefore, this review will accept that childhood neglect is associated with the attention shifting domain.

\section{Spatial Planning}

One study Hanson (2013) et al. [38] found that children who suffered early neglect completed fewer problems on the subtest of the CANTAB is the Stockings of Cambridge (SOC) test, in the minimum number of moves $(\mathrm{F}=8.797, \mathrm{p}=.005)$, compared to the control group. The other two studies found that childhood 
neglect did not have an impact on spatial planning. Bick et al. [39] found that the number of problems completed in the minimum number of moves did not significantly vary between children with or without histories of institutional/neglect rearing $(\beta=-.224$, $\mathrm{p}<.013)$. Similar results were found by Pollak et al. (2010) [40], post-institutionalized (neglected) children performed well on tests of executive processing involving manipulation and spatial planning ( $p>$.05). The included studies found mixed results, but with more studies finding that neglect did not have an impact on spatial planning. Neglected children are often left alone to deal with their environment so they adjust and learn themselves. Therefore, when it comes to tasks of planning and solving, they are superior compared to other children Maguire (2015) et al. [7]. Hence, this review will accept that childhood neglect is not associated with the spatial planning domain.

\section{Academic Achievement}

Two studies used school grades to assess academic achievement. One study Manly (2013) et al. [42] found that childhood neglect was associated with diminished language arts, in kindergarten. Neglect was also associated with mathematics results, in first-grade, and poorer results in general in first-grade academic achievement. Nevertheless, neglect severity was found to not be directly related to first-grade academic achievement, but rather indirectly associated with cognitive function. However, McGuire and Jackson (2018) [43] found that emotional abuse severity and physical abuse was a significant predictor of English grades. Neglect was found to not be a significant predictor of grades and no variables predicted mathematics grades. Only neglect frequency was a substantial predictor of English grades $(B=0.17, p=.06)$. Petrenko (2012) et al. [44] used the Wechsler Individual Achievement Test (WIAT) and found similar results to McGuire and Jackson (2018) [43]. Physical neglect and supervisory neglect did not predict academic achievement when using the WIAT test. The only significant predictor of lower academic achievements was having a previous period of out-of-home care ( $\mathrm{B}=-3.55, \mathrm{t}=-2.24, \mathrm{p}=.026)$.

Petrenko (2012) et al. [44] and McGuire and Jackson (2018) [43] use different measurement tools, but both found that childhood neglect was not associated with academic achievement York (2015) [45]. Both studies focused on older children and who had been in foster care [41] or in out-of-home care [42]. Whereas, manly who found that childhood neglect was associated with language arts and mathematics, focused on younger children and those recruited through the Department of Health Services (DHS). Given the variances in data collections techniques, for example, how neglect was recorded, inconsistencies between studies are common. These discrepancies partially explain differences in association with academic functions [43]. Moreover, another reason for the discrepancy in study's findings could be due to the variation of what is deemed as academic achievement. From the included articles, given that there were mixed results and more studies found no association, this review will accept that childhood neglect is not associated with academic achievement.

\section{Language}

Two studies used the Clinical Evaluation of Language Fundamentals (CELF) test and both studies found that childhood neglect did not correlate with language. De Bellis, Woolley and Hooper (2013) [46] Lum (2018) et al. [47]. De Bellis (2013) et al. found that only sexual abuse significantly and negatively correlated with language $(\mathrm{p}<.05)$. Similar results by Lum, Powell and Snow (2018) [47] found on a group level (neglect, emotional abuse, physical abuse, and sexual abuse), language skills are, on average, below the normative mean $(\mathrm{t}(82)=5.013, \mathrm{p}<.001)$. However, when neglect was considered on its own, children's overall language functioning was not found to be related to neglect.

Whereas Spratt (2012) et al. [48] who used the Test of Early Language Development (TELD) found that when adjusting for socioeconomic status, participants in the control group displayed higher levels of language functioning than both neglect groups. The control group performed significantly better than the United States children with a history of physical or emotional neglect (USN) group on TELD receptive $(\mathrm{p}=.004)$, expressive $(\mathrm{p}=.006)$ and oral composite $(\mathrm{p}=.002)$. Children in the control group performed significantly better than children in the adopted from international institutions (IA) group on TELD receptive $(\mathrm{p}=.002)$, expressive $(\mathrm{p}<.001)$ and oral composite $(\mathrm{p}<.001)$.

The included articles in this review, found mixed results when it came to the association between childhood neglect and language. An explanation for the studies that found no association could be due to the measurement tool used. Despite the CELF's effort to formulate a comprehensive language tool, it lacks validity due to a misleading standardized sample and an inadequate reference standard Paslawski (2007) [49]. There is also an absence of data as to how items and tasks are considered appropriate. As the CELF is mainly vocabulary based, it will tend to recognize the socioeconomic status and second language acquisition concerns, rather than language development concerns, due to the significant linguistic, cultural and socioeconomic bias [49]. These concerns with the CELF could explain why the two studies De Bellis et al. $[46,47]$ in this review found no association between neglect and language. Therefore, this review will accept that childhood neglect is associated with language.

\section{Memory}

Three studies used the Paired Associated Learning (PAL) test, to assess memory. One study Pollak et al. (2010) [40] discovered that post-institutionalized children significantly scored lower than the other two groups, $F(2,131)=12.47, \mathrm{p}=.001$. Similar results were found by Hanson (2013) et al. [38]. Moreover, Bick et al. found that children in the institutionalized group made significantly more errors before completing a stage $(\beta=-.254, \mathrm{p}=.005)$. However, 
after controlling for Intelligence Quotient (IQ), the number of levels completed did not differ between the ever and never institutionalized groups. The association between institutional rearing status and performance on any of the PAL subscales was no longer significant Bick (2018) et al. [39].

The studies that used the California Verbal Learning Test (CVLT) found that memory ability in children who had been neglected or abused was no different to children in the control group Cicchetti (2010) [50]. Cicchetti established that the experience of childhood neglect or abuse does not necessarily unfavorably affect, nor does it improve, basic memory (recall and recognition memory) for nontraumatic material De Bellis et al. (2013). De Bellis also used the CVLT test and found that only sexual abuse significantly and negatively correlated with memory.

Finally, Chae (2011) et al. [51] used the short-term memory subtest of the SB5. They found that there were no significant abuse or neglect differences or age and neglect/abuse interactions found in children's memory functioning. The included articles in this review, found mixed results when it came to the association between child neglect and memory. However, after controlling for confounder variables, most studies found that neglect had no significant impact on memory performance. Therefore, this review will accept that childhood neglect is not associated with memory.

\section{Intelligence}

All studies recognized a negative association between childhood neglect and IQ scores even after adjusting confounders. One study Bengwasan (2018) [52] used the Full-Scale Intelligence Quotient (FSIQ) which is comprised of non-verbal IQ (NVIQ) and verbal IQ (VIQ) and found significant differences between the groups, $F(2$, 297)=16.766, $p<.001$. The children in the physically abused group $(M=76.550, S D=11.515)$ had the highest FSIQ mean score, compared to children in the sexually abused group, $(M=72.340, S D=12.324)$ and the neglected group, $(M=66.99, S D=11.227)$. (Manly (2013) et al. [42]; O'Hara (2015) et al. [53]) Two studies used the Wechsler Preschool and Primary Scale of Intelligence (WPPSI-R). One study (Manly et al., 2013) found a significant negative association between the severity of neglect to the IQ of children, after controlling for maternal IQ and demographic covariates. Severe neglect before the age of 4 was associated with diminished IQ at age 4. However, the link from IQ at age 4 and first-grade academic function at age 6 was statistically insignificant $(\beta=-0.008, p=.216)$. Moreover, another study (O'Hara et al., 2015) using the WPSSI-R found that neglected children scored significantly worse than children who had been neglected and abused $(\mathrm{p}=0.03)$. However, the groups did not differ on the block design subtest $(\mathrm{p}=0.4)$. One study Petrenko et al. (2012) used the Kaufman Brief Intelligence Test (K-BIT) to measure intelligence. They found that the supervisory neglect group had better verbal IQ scores than the physical neglect group $(\beta=-4.00, p=.026)$ and higher verbal IQ scores than children in the sexual abused/mixed class group ( $p=.009)$. Most studies included in this review found there was an association between child neglect and intelligence. Therefore, this review will accept that childhood neglect is associated with intelligence.

\section{Discussion}

The findings from this review provided evidence that child neglect is associated with cognitive function and does have an impact on domains such as executive function (working memory and attention shifting), language and intelligence. However, the articles included in this review also found no association between neglect and executive function (spatial planning), academic achievement and memory. Although the findings from the 13 included articles found mixed results with regards to the association between child neglect and cognitive function. It is clear from the findings and previous research the difficulties that children with neglect face, from poverty to a lack of parental care, impacting their growth and well-being Rutter and Sroufe, (2000). This demonstrates the detrimental effects of not just neglect, but ACEs in general.

\section{Limitations}

In the included studies, the definition of neglect was highly variable. This made it difficult to make comparisons and similarities between the studies. Due to high heterogeneity, this precluded the use of a meta-analysis and justified the use of narrative synthesis Higgins (2009) [33]. It could be argued if there is no single operational definition for neglect, this makes it challenging to interpret and compare the findings of the research and to establish whether children are eligible for services. Moreover, in many of the included studies, the use of a wide range of age groups meant it was impossible to make comparisons and similarities between the studies. It can be argued that different regions of the brain develop at different stages. Therefore, this may be the reason there is a difference between two studies using different age bands, instead of it being as a result of childhood neglect.

\section{Recommendations for Practice}

Several recommendations for education professionals can be made based on the findings of this scoping review. Understanding the nature and frequency of ACEs in school-aged children, particularly at a young age (6-12 years of age) can guide teachers who feel they lack the knowledge of indicating neglect. By recognizing neglect and intervening early, teachers can help children who have been neglected to attain better performance in school. Recognising the impact of neglect on children can help to understand why classrooms can be challenging and upsetting places for these children. Consistent with the findings from this review and previous research, neglected children have enhanced problem solving and spatial planning skills, so these children may sometimes be seen as more independent than other children Maguire et al. (2015) [7]. At the same time, they may also have 
difficulty with classroom routines and other elements. Therefore, if teachers are aware of these styles of cognitive features, then child neglect can be recognized early on. Moreover, by understanding childhood neglect in school-aged children, research can help to justify the allocation of resources at a widespread level within a multitiered framework [54].

\section{Conclusion}

It is hoped that the results of this review will offer support for a universal definition of childhood neglect. Moreover, by understanding childhood neglect in school-aged children can also help to build on teachers knowledge of neglect and justify the allocation of resources at a widespread level within a multitiered framework

\section{References}

1. Felitti VJ, Anda RF, Nordenberg D, Williamson DF, Spitz AM (1998) Relationship of childhood abuse and household dysfunction to many of the leading causes of death in adults. American Journal of Preventive Medicine 14(4): 245-258.

2. McLaughlin KA, Weissman D, Bitran D (2019) Childhood adversity and neural development: A systematic review. Annual Review of Developmental Psychology 1: 277-312.

3. Peterson A, Joseph J, Feit M (2013) New Directions in Child Abuse and Neglect Research. Washington DC: The National Academies Press.

4. Hughes K, Bellis MA, Hardcastle KA, Sethi D, Butchart A (2017) The effect of multiple adverse childhood experiences on health: a systematic review and meta-analysis. Lancet Public Health 2(8): e356-e366.

5. Evans GW, Li D, Whipple SS (2013) Cumulative risk and child development. Psychological Bulletin 139(6): 1342-1396.

6. English DJ, Thompson R, Graham JC, Briggs EC (2005) Toward a definition of neglect in young children. Child Maltreatment 10 (2): 190-206.

7. Maguire SA, Williams B, Naughton AM, Cowley LE, Tempest V (2015) A systematic review of the emotional, behavioural and cognitive features exhibited by school-age children experiencing neglect or emotional abuse. Child: Care, Health and Development 41(5): 641-653.

8. Dubowitz H, Pitts SC, Black MM (2004) Measurement of three major subtypes of child neglect. Child Maltreatment 9(4): 344-356.

9. De Bellis MD (2005) The psychobiology of neglect. Child Maltreatment 10(2): 150-172.

10. Rutter M, Sroufe LA (2000) Developmental psychopathology: Concepts and challenges. Development and Psychopathology 12(3): 265-296.

11. (2002) Great Britain Education Act of 2002. HMSO: London.

12. Burgess C, Daniel B, Scott J, Mulley K, Derbyshire D (2012) Child Neglect in 2011: An Annual Review by Action for Children in Partnership with the University of Stirling. Action for children.

13. McGarry K, Buckley H (2013) Lessons on child protection: A survey of newly qualified primary-level teachers in Ireland. Child Abuse Review 22(2): 80-92.

14. GilbertR, Kemp A, Thoburn J, Sidebotham P, Radford L (2009) Recognising and responding to child maltreatment. The Lancet 373(9658): 167-180.

15. Nisbett RE, Aronson J, Blair C, Dickens W, Flynn J, Halpern DF, Turkheimer E (2012) Intelligence: new findings and theoretical developments. American Psychologists 67(2): 130-159.
16. Noble KG, Tottenham N, Casey BJ (2005) Neuroscience perspectives on disparities in school readiness and cognitive achievement. Future Child 15(1): 71-89.

17. Guinosso SA, Johnson SB, Riley AW (2016) Multiple adverse experiences and child cognitive development. Pediatric Research 79(1): 220-226.

18. Woolfolk A (2007) Educational Psychology. Boston: Pearson.

19. Erickson M, Egeland B, Pianta R (1989) The effects of maltreatment on the development of young children. In: Cicchetti D and Carlson V (Eds.), Child maltreatment: Theory and research on the causes and consequences of child abuse and neglect. New York, NY: Cambridge University Press pp. 647-684.

20. Egeland B (1991) A longitudinal study of high-risk families: Issues and findings. In: Starr RH, Wolfe DA (Eds.), The effects of child abuse and neglect: Issues and research. Guilford Press, New York, USA, pp. 33-56.

21. Egeland B (1997) Mediators of the effects of child maltreatment on developmental adaptation in adolescence. In: Cicchetti D, Toth SL (Eds.), Rochester symposium on developmental psychopathology, Developmental perspectives on trauma: Theory, research, and intervention. Rochester, NY: University of Rochester Press, USA, 8: 403434.

22. Trask RL (2007) Language and Linguistics: The Key Concepts. London, UK: Routledge.

23. Eigsti IM, Cicchetti D (2004) The impact of child maltreatment on expressive syntax at 60 months. Developmental Science 7 (1): 88-102.

24. Allen J, Oliver JM (1982) The effects of child maltreatment on language development. Child Abuse \& Neglect 6(3): 299-305.

25. Culp RE, Watkins RV, Lawrence H, Letts D, Kelly DJ (1991) Maltreated children's language and speech development: abused, neglected, and abused and neglected. First Language 11(33): 377-389.

26. Kavanaugh BC, Dupont Frechette JA, Jerskey BA, Holler KA (2017) Neurocognitive deficits in children and adolescents following maltreatment: neurodevelopmental consequences and neuropsychological implications of traumatic stress. Applied Neuropsychology Child 6(1): 64-78.

27. Carlson JS, Yohannan J, Darr CL, Turley MR, Larez NA (2019) Prevalence of adverse childhood experiences in school-aged youth: a systematic review (1990-2015) International Journal of School \& Educational Psychology 8(Suppl-1).

28. Yingying SD, Arcy C, Shuai Y, Xiangfei M (2019) How does childhood maltreatment influence ensuing cognitive functioning among people with the exposure of childhood maltreatment? A systematic review of prospective cohort studies. Journal of Affective Disorder 252: 278-293.

29. McLaughlin KA, Sheridan MA, Lambert HK (2014) Childhood adversity and neural development: deprivation and threat as distinct dimensions of early experience. Neuroscience and Biobehavioral Reviews 47: 578591.

30. Moher D, Liberati A, Tetzlaff J, Altman DG, The PRISMA Group (2009) Preferred reporting items for systematic reviews and meta-analyses: the PRISMA statement. PLoS Med 6(7): e1000097.

31. (1999) World Health Organisation. Report of the Consultation on Child Abuse Prevention WHO, Geneva, 29-31 March 1999.

32. Moher D, Hopewell S, Schulz KF, Montori V, Gotzsche PC (2010) CONSORT 2010 explanation and elaboration: updated guidelines for reporting parallel group randomised trials. British Medical Journal 340: 1-28.

33. Whiting P, Wolff R, Mallett S, Simera I, Savovic J (2017) A proposed framework for developing quality assessment tools. Systematic Reviews 6(204): 1-9. 
34. Higgins JPT, Thompson SG, Spiegelhalter DJ (2009) A re-evaluation of random effects meta-analysis. Journal of the Royal Statistical Society. Series A 172(1): 137-159.

35. Higgins JPT, Thomas J, Chandler J, Cumpston M, Li T (2019) Cochrane Handbooks for Systematic Reviews of Interventions. In Higgins JPT, Thomas J, Chandler J, Cumpston M, Li T (Eds.), Chichester, John Wiley \& Sons, UK

36. Stuss DT, Alexander MP (2000) Executive functions and the frontal lobes: A conceptual view. Psychological Research 63(3-4): 289-298.

37. Blair C, Zelazo PD, Greenberg M (2005) The assessment of executive function in early childhood: Prospects and progress. Developmental Neuropsychology 28: 561-571.

38. Hanson JL, Adluru N, Chung MK, Alexander AL, Davidson RJ (2013) Early neglect is associated with alterations in white matter integrity and cognitive functioning. Child Development 84(5): 1-23.

39. Bick J, Zeanah C, Fox NA, Nelson C (2018) Memory and executive functioning in 12-year-old children with histories of institutional rearing. Child Development 89(2): 495-508.

40. Pollak SD, Nelson CA, Schlaak MF, Roeber BJ, Wewerka SS (2010) Neurodevelopmental effects of early deprivation in post-institutionalized children. Child Development 81(1): 224-236.

41. Anderson P (2010) Assessment and development of executive function (EF) during childhood. Child Neuropsychology 8(2): 71-82.

42. Manly JT, Lynch M, Oshri A, Herzog M, Wortel SN (2013) The impact of neglect on initial adaption to school. Child Maltreatment 18 (3): 155170.

43. McGuire A, Jackson Y (2018) Dimensions of maltreatment and academic outcomes for youth in foster care. Child Abuse \& Neglect 84: 82-94.

44. Petrenko CLM, Friend A, Garrido EF, Taussig HN, Culhane SE (2012) Does subtype matter? Assessing the effects of maltreatment on functioning in preadolescent youth in out-of-home care. Child Abuse \& Neglect 36(9): 633-644.

\section{ISSN: 2574-1241}

DOI: 10.26717/BJSTR.2021.34.005629

Gemma Trainor. Biomed J Sci \& Tech Res

(C) This work is licensed under Creative

Submission Link: https://biomedres.us/submit-manuscript.php
45. York TT, Gibson C: Rankin S (2015) Defining and measuring academic success. Practical Assessment, Research and Evaluation 20(5): 1-21.

46. De Bellis MD, Woolley DP, Hooper SR (2013) Neuropsychological findings in pediatric maltreatment: Relationship of PTSD, dissociative symptoms, and abuse/neglect indices to neurocognitive outcomes. Child Maltreatment 18(3): 171-183.

47. Lum JAG, Powell M, Snow PC (2018) The influence of maltreatment history and out-of-home care on children's language and social skills. Child Abuse \& Neglect 76: 65-74

48. Spratt EG, Friedenberg SL, Swenson CC, LaRosa A, De Bellis MD (2012) The effects of early neglect on cognitive, language and behavioral functioning in childhood. Psychology (Irvine) 3(2): 175-182.

49. Paslawski T (2007) The clinical evaluation of language fundamentals. In Paslawski T(Eds.), (4 ${ }^{\text {th }}$ edn.), Canadian Journal of School Psychology 20(2): 129-134.

50. Cicchetti D, Rogosch FA, Howe ML, Toth SL (2010) The effects of maltreatment and neuroendocrine regulation on memory performance. Child Development 81(5): 1504-1519.

51. Chae Y, Goodman GS, Eisen ML, Qin J (2011) Event memory and suggestibility in abused and neglected children: Trauma-related psychopathology and cognitive functioning. Journal of Experimental Child Psychology 110(4): 520-538.

52. Bengwasan PD (2018) The intellectual profile of abused and neglected children in the Philippines: An analysis of SB5 IQ scores of sexually abused, physically abused and neglected children. Child Abuse \& Neglect 81: 389-395.

53. O Hara M, Legano L, Homel P, Walker Descartes I, Rojas M (2015) Children neglected: Where cumulative risk theory fails. Child Abuse \& Neglect 45: 1-8.

54. Chafouleas SM, Johnson AH, Overstreet S, Santos NM (2016) Toward a blueprint for trauma-informed service delivery in schools. School Mental Service 1: 144-162.

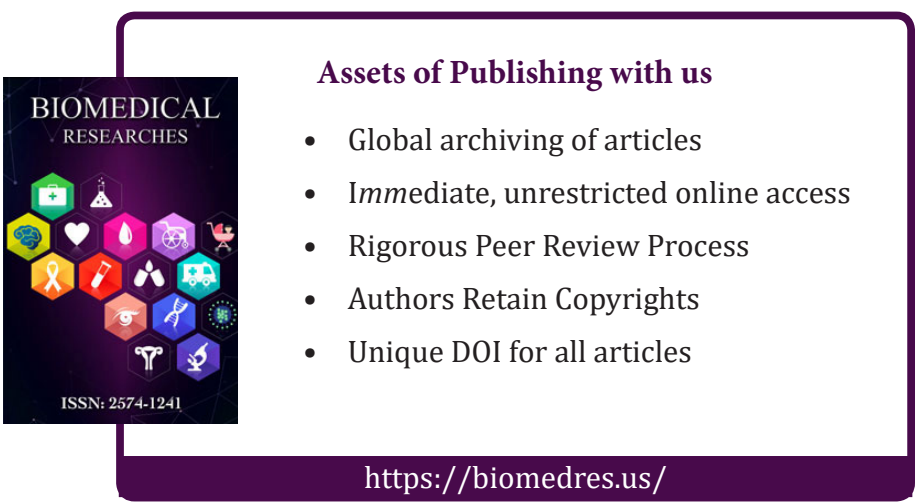

